\title{
AKRUAL
}

Jurnal Akuntansi

http://fe.unesa.ac.id/ojs/index.php/akrl

\section{PENGARUH KUALITAS PELAYANAN TERHADAP KEPUASAN \\ NASABAH \\ DI PT. BANK CENTRAL ASIA (BCA) TbK CABANG UNDAAN SURABAYA}

\author{
Yulian Belinda Ambarwati \\ STIE Perbanas Surabaya \\ Email : yulian@perbanas.ac.id
}

Artikel diterima: 14 Mei 2014

Terakhir direvisi: 27 Juli 2014

\begin{abstract}
This study aims to determine the effect of Quality of Service Characteristics on Customer Satisfaction in the PT. Bank Central Asia (BCA) Branch Surabaya Undaan. The sampling in this study using stratified sampling (Stratified Random Sampling). Analysis techniques that are used are double linear regression. The calculation result shows that the quality of services simultaneous effect on customer satisfaction in PT. Bank Central Asia (BCA) Branch Surabaya Undaaan. The quality of services that include variables Responsiveness, Tangibles, Empathy, Assurance, and Reliability in a partial effect on customer satisfaction in PT. Bank Central Asia (BCA) Branch Surabaya undaaan.
\end{abstract}

Keywords: Responsiveness, Tangibles, Empathy, Assurance, Reliability and customer satisfaction.

\section{PENDAHULUAN}

Dunia bisnis, merupakan dunia yang paling ramai dibicarakan diberbagai forum, baik yang bersifat nasional maupun internasional. Ramainya pembicaraan masalah ini disebabkan, salah satu tolak ukur kemajuan suatu negara adalah dari kemajuan ekonominya dan tulang punggung dari kemajuan ekonomi adalah dunia bisnis. Masalah pokok dan paling sering dihadapi oleh setiap perusahaan yang bergerak dalam bidang usaha apapun selalu tidak terlepas dari kebutuhan akan dana (modal) untuk membiayai usahanya. Kebutuhan akan dana ini diperlukan baik untuk modal investasi atau modal kerja. Dana memang dibutuhkan baik untuk perusahaan yang baru berdiri maupun sudah berjalan bertahun-tahun.

Usaha keuangan dilaksanakan oleh perusahaan yang bergerak di bidang keuangan atau yang sering kita sebut dengan lembaga keuangan. Bank merupakan lembaga keuangan yang memberikan jasa keuangan yang paling lengkap. Usaha keuangan yang dilakukan disamping menyalurkan dana atau memberikan pinjaman (kredit) juga melakukan usaha menghimpun dana dari masyarakat luas dalam bentuk simpanan. Kemudian usaha bank lainnya memberikan jasa-jasa keuangan yang mendukung dan memperlancar kegiatan memberikan pinjaman dengan kegiatan menghimpun dana. 
Bank adalah salah satu bentuk bisnis yang memiliki prospek dinamis dengan tingkat persaingan yang cukup tinggi. Kini konsumen semakin pintar dan selektif dalam setiap pengambilan keputusan penggunaan layanan. Untuk itulah bank dituntut untuk memberikan pelayanan yang optimal untuk mempertahankan kepuasan nasabah. Bagi nasabah pelayanan yang bermutu sangat penting. Menurut Royne dalam Tatik Suryani (2001:273), "kualitas pelayanan menjadi komponen utama karena produk-produk utama bank yaitu kredit merupakan suatu penawaran yang tidak berbeda dan pelayanan bank juga mudah ditiru". Oleh karena itu persaingan akan sangat dipengaruhi oleh kemampuan bank memberikan pelayanan terbaik yang bermutu dibandingkan pesaingnya.

Era sekarang ini yang ditandai oleh revolusi teknologi komunikasi dan informasi mengakibatkan terjadinya perubahan (change) yang luar biasa. Adanya kemudahan yang diperoleh dari komunikasi dan informasi muncul kompetisi yang sangat ketat yang berakibat pelanggan (customer) semakin banyak pilihan dan sangat sulit untuk dipuaskan karena telah terjadi pergeseran yang semula hanya untuk memenuhi kebutuhan, meningkat menjadi harapan (expectation) untuk memenuhi kepuasan. Sehingga bagi perusahaan, kunci kearah profitabilitas bukan lagi volume penjualan melainkan kepuasan jangka panjang bagi pelanggan.

Kualitas dan kepuasan pelanggan berkaitan erat. Kualitas memberikan suatu dorongan kepada pelanggan untuk menjalin ikatan yang kuat dengan perusahaan. Ikatan seperti ini dalam jangka panjang memungkinkan perusahaan untuk memahami dengan seksama harapan pelanggan serta kebutuhan mereka, dengan demikian perusahaan tersebut dapat meningkatkan kepuasan pelanggan dimana perusahaan memaksimumkan pengalaman pelanggan yang menyenangkan dan meminimumkan atau meniadakan pengalaman pelanggan yang kurang menyenangkan. Orientasi pada kepuasan nasabah diperlukan karena:

1. Nasabah akan merasa loyal kepada bank sehingga bank dapat mempertahankan nasabahnya tidak beralih ke bank lainnya.

2. Nasabah akan menceritakan mengenai pelayanan bank yang memuaskan kepada orang lain yang pada akhirnya merupakan sarana promosi yang efektif (Sunardi, 2003 : 69).

Perusahaan yang gagal memuaskan pelayanannya akan menghadapi masalah yang kompleks. Umumnya pelanggan yang tidak puas akan menyampaikan pengalaman buruknya kepada orang lain dan bisa dibayangkan betapa besarnya kerugian dari kegagalan memuaskan pelanggan. Oleh karena itu, setiap perusahaan jasa wajib merencanakan, mengorganisasikan, mengimplementasikan, dan mengendalikan sistem kualitas sedemikian rupa, sehingga pelayanan dapat memuaskan para pelanggannya. Penilaian akan kualitas layanan dikembangkan oleh Leonard L. Barry, A. Parasuraman dan Zeithaml yang dikenal dengan service quality (SERVQUAL), yang berdasarkan pada lima dimensi kualitas yaitu tangibles (bukti langsung), reliability (kehandalan), responsiveness (daya tanggap), assurance (jaminan) dan empathy (empati) (Kotler, 1997:53). Bisnis perbankan merupakan bisnis yang berdasarkan pada azas kepercayaan, masalah kualitas layanan (service quality) menjadi faktor penting dalam menentukan keberhasilan bisnis ini. Hal itu juga terjadi di Bank Central Asia (BCA) Tbk Cabang Undaan Surabaya sebagai tempat penelitian ini, kualitas pelayanan merupakan hal penting yang perlu diperhatikan. 
adalah:

Berdasarkan latar belakang diatas maka rumusan masalah penelitian ini

1. Apakah kualitas pelayanan di PT. Bank Central Asia (BCA) Tbk Cabang Undaan Surabaya yang meliputi variabel responsiveness, tangibles, reliability, assurance, dan empathy secara simultan berpengaruh terhadap kepuasan para nasabah?

2. Apakah kualitas pelayanan di PT. Bank Central Asia (BCA) Tbk Cabang Undaan Surabaya yang meliputi variabel responsiveness, tangibles, reliability, assurance, dan empathy secara parsial berpengaruh terhadap kepuasan para nasabah?

Tujuan dari penelitian ini adalah :

1. Menganalisis apakah kualitas pelayanan di PT. Bank Central Asia (BCA) Tbk Cabang Undaan Surabaya yang meliputi variabel responsiveness, tangibles, reliability, assurance, dan empathy secara simultan berpengaruh terhadap kepuasan para nasabah.

2. Menganalisis apakah kualitas pelayanan di PT. Bank Central Asia (BCA) Tbk Cabang Undaan Surabaya yang meliputi variabel responsiveness, tangibles, reliability, assurance, dan empathy secara parsial berpengaruh terhadap kepuasan para nasabah.

\section{KAJIAN PUSTAKA \\ Kualitas}

Berdasarkan kualitas, baik yang konvensional maupun yang lebih strategis oleh Gasperz (1997) dinyatakan bahwa pada dasarnya kualitas mengacu kepada pengertian pokok yaitu kualitas terdiri dari sejumlah keistimewaan produk, baik keistimewaan langsung, maupun keistimewaan atraktif yang memenuhi keinginan pelanggan dan dengan demikian memberikan kepuasan atas penggunaan produk. Kualitas terdiri dari segala sesuatu yang bebas dari kekurangan atau kerusakan. Berikut ini adalah definisi kualitas yang dikemukakan oleh para ahli (Suardi, 2003, pp 2-3) :

1. Crosby berpendapat bahwa mutu atau kualitas berarti kesesuaian terhadap persyaratan, seperti jam tahan air, sepatu tahan lama, atau dokter yang ahli. Crosby juga mengemukakan pentingnya melibatkan setiap orang pada proses dalam organisasi.

2. Deming berpendapat bahwa kualitas berarti pemecahan masalah untuk mencapai penyempurnaan terus-menerus, contohnya dengan menerapkan kaizen di perusahaan.

3. Juran berpendapat bahwa kualitas berarti kesesuaian dengan penggunaan, seperti sepatu yang dirancang untuk olahraga atau sepatu kulit yang dirancang untuk ke kantor atau ke pesta. Pendekatan Juran merupakan orientasi pada upaya pemenuhan harapan pelanggan.

4. Ishikawa berpendapat bahwa kualitas berarti kepuasan pelanggan. Dengan demikian, setiap bagian proses dalam organisasi memiliki pelanggan. Kepuasan pelanggan internal akan meyebebkan kepuasan pelanggan organisasi 


\section{Pelayanan}

Pelayanan adalah suatu kegiatan atau urutan kegiatan yang terjadi dalam interaksi langsung antara seseorang dengan orang lain atau mesin secara fisik, dan menyediakan kepuasan pelanggan. Gronroos (Ratminto dan Anti Septi Winarsih, 2005 ; 2) mengatakan : Pelayanan adalah suatu aktivitas atau serangkaian aktivitas yang bersifat tidak kasat mata (tidak dapat diraba) yang terjadi sebagai akibat adanya interaksi antara konsumen dengan karyawan atau hal-hal lain yang disediakan oleh perusahaan pemberi pelayanan yang dimaksudkan untuk memecahkan permasalahan konsumen atau pelanggan. Menurut Drs. Sutopo, MPA pelayanan adalah suatu usaha untuk membantu menyiapkan (mengurus) apa yang diperlukan oleh orang lain baik berupa barang maupun jasa. Dari definisi tersebut dapat diketahui bahwa ciri pokok pelayanan adalah tidak kasat mata (tidak dapat diraba) dan melibatkan upaya manusia (karyawan) atau peralatan lain yang disediakan oleh perusahaan penyelenggara pelayanan.

\section{Kualitas Pelayanan}

Bagi pelanggan kualitas pelayanan adalah menyesuaikan diri dengan spesifikasi yang dituntut pelanggan. Pelanggan memutuskan bagaimana kualitas yang dimaksud dan apa yang dianggap penting. Pelanggan atau nasabah mempertimbangkan suatu kualitas pelayanan. Untuk itu kualitas dapat dideteksi pada persoalan bentuk, sehingga dapat ditemukan, kualitas pelayanan merupakan bentuk dari sebuah janji dan kualitas adalah tercapainya sebuah harapan dan kenyataan sesuai komitmen yang telah ditetapkan sebelumnya.

Kualitas pelayanan adalah suatu kegiatan pelayanan yang diberikan kepada pelanggan sesuai dengan prinsip; lebih mudah, lebih baik, cepat, tepat, akurat, ramah, sesuai dengan harapan pelanggan. Kualitas pelayanan juga dapat diartikan sebagai kegiatan pelayanan yang diberikan kepada seseorang atau orang lain, organisasi pemerintah maupun swasta sesuai dengan peraturan perundangundangan yang berlaku. Standar kualitas pelayanan menurut Lupiyoadi (2004:196) adalah : tingkat keaktifan bank atau karyawan dalam melayani calon nasabah, tingkat keramahan bank atau karyawan dalam menghadapi calon nasabah, tingkat penjelasan produk yang ditawarkan oleh bank kepada calon nasabah, dan tingkat demonstrasi yang diajukan oleh bank terhadap calon nasabah.

\section{Prinsip Pelayanan}

Menurut Rahmayanty (2010:88), prinsip pelayanan meliputi:

1. Kesederhanaan; prosedur pelayanan tidak berbelit-belit, mudah dipahami dan mudah dilaksanakan.

2. Kejelasan; persyaratan teknis dan administratif pelayanan, unit kerja atau pejabat yang berwenang dan bertanggungjawab dalam memberikan pelayanan dan penyelesaian keluhan atau persoalan dalam pelaksanaan pelayanan, serta rincian biaya pelayanan dan tata cara pembayaran.

3. Kepastian waktu; pelaksanaan pelayanan dapat diselesaikan dalam kurun waktu yang ditentukan.

4. Akurasi; produk pelayanan diterima dengan benar, tepat, dan sah. 
5. Keamanan; proses dan produk pelayanan memberikan rasa aman dan kepastian hukum.

6. Tanggungjawab; pimpinan penyelenggara pelayanan atau pejabat yang ditunjuk bertanggungjawab atas penyelenggaraan pelayanan dan penyelesaian keluhan atau persoalan dalam pelaksanaan pelayanan.

7. Kelengkapan sarana dan prasarana; tersedianya sarana dan prasarana kerja, peralatan kerja dan pendukung lainnya yang memadai termasuk penyediaan sarana teknologi telekomunikasi dan informatika.

8. Kemudahan akses; tempat dan lokasi serta sarana pelayanan yang memadai, mudah dijangkau oleh masyarakat, dan dapat memanfaatkan teknologi telekomunikasi dan informatika.

9. Kedisiplinan, kesopanan, dan keramahan; pemberi pelayanan harus bersikap disiplin, sopan dan santun, ramah, serta memberikan pelayanan dengan ikhlas.

10. Kenyamanan; lingkungan pelayanan harus tertib, teratur, disediakan ruang tunggu yang nyaman, bersih, rapi, lingkungan yang indah dan sehat serta dilengkapi dengan fasilitas pendukung pelayanan seperti parkir, toilet, tempat ibadah, dan lain-lain.

\section{Standar Pelayanan}

Semua organisasi yang menghasilkan produk barang maupun jasa pelayanan harus mempunyai standar pelayanan yang baku untuk menjamin kepastian bagi pengguna jasa pelayanan atau penerima pelayanan. Standar pelayanan ini akan menjadi ukuran dalam menyelenggarakan pelayanan kepada pelanggan. Standar pelayanan yang sudah dibukukan harus ditaati oleh masing-masing pihak yaitu pemberi dan penerima pelayanan. Standar pelayanan meliputi :

1. Prosedur pelayanan

Prosedur pelayanan yang dibakukan bagi pemberi dan penerima pelayanan termasuk pengaduan.

2. Waktu penyelesaian

Waktu penyelesaian yang ditetapkan sejak saat pengajuan permohonan sampai penyelesaian pelayanan termasuk pengaduan. Disini waktu yang diperlukan dalam pelayanan harus benar-benar diperhatikan. Tanpa adanya kepastian waktu maka pelayanan tidak akan memberikan kepuasan kepada pelanggan.

3. Biaya pelayanan

Biaya atau tarif pelayanan termasuk rinciannya yang ditetapkan dalam proses pemberian pelayanan. Dalam rangka memberikan kepuasan kepada pelanggan besarnya biaya harus pasti dan harus diketahui secara umum, sehingga siapapun yang memerlukan jasa pelayanan sudah tahu akan biaya yang akan dikeluarkan.

4. Produk pelayanan

Hasil pelayanan yang akan diterima pelanggan harus sesuai dengan ketentuan yang telah ditetapkan. Pelanggan akan merasa puas apabila produk yang diterima sesuai standar yang telah ditetapkan sebelumnya. Begitu juga sebaliknya apabila produk pelayanan yang diterima pelaggan tidak sesuai dengan standar pelanggan yang ada maka pelanggan akan merasa kecewa sehingga pelanggan atau nasabah tidak merasa puas yang akan mengakibatkan 
loyalitas pelanggan terhadap produk pelayanan akan luntur dan akhirnya akan berdampak negative terhadap organisasi pemberi jasa pelayanan.

5. Sarana dan prasarana

Penyediaan sarana dan prasarana pelayanan yang memadai oleh penyelenggara pelayanan publik. Sarana dan prasarana yang ada akan berdampak terhadap pelayanan yang diberikan kepada pelanggan. Tersedianya sarana dan prasarana yang memadai akan memberikan kenyamanan bagi pelanggan.

6. Kompetensi petugas pemberi pelayanan

PT. Bank Central Asia (BCA) Tbk Cabang Undaan juga mempunyai standar pelayanan. Standar layanan ini disusun untuk dilaksanakan bersama - sama oleh seluruh keluarga besar BCA, baik di kantor pusat, kantor wilayah, maupun kantor cabang.

Standar layanan di PT. Bank Central Asia (BCA) Tbk Cabang Undaan Surabaya adalah layanan harus senantiasa diberikan secara Sigap, Menarik, Antusias, Ramah, dan Teliti (SMART).

\section{Lembaga Keuangan (Bank)}

Menurut undang-undang RI nomor 10 tahun 1998 tanggal 10 November 1998 tentang perbankan, yang dimaksud Bank adalah badan usaha yang menghimpun dana dari masyarakat dalam bentuk simpanan dan menyalurkannya kepada masyarakat dalam bentuk kredit dan atau bentuk-bentuk lainnya dalam rangka meningkatkan taraf hidup orang banyak. Lembaga keuangan (Bank) merupakan lembaga keuangan yang memberikan jasa keuangan yang paling lengkap. Usaha keuangan yang dilakukan disamping menyalurkan dana atau memberikan pinjaman (kredit) juga melakukan usaha menghimpun dana dari masyarakat luas dalam bentuk simpanan. Fungsi perbankan menurut pasal 3 UU No. 10 tahun 1998 tentang perbankan menjelaskan bahwa fungsi perbankan indonesia adalah menghimpun dana dan kemudian menyalurkan dana itu ke masyarakat.

\section{Kepuasan Nasabah}

Menurut Kotler, kepuasan adalah tingkat perasaan seseorang setelah membandingkan kinerja atau hasil yang dia rasakan dibandingkan dengan harapannya (Kotler dkk, 2000 :52). Wilkie (1990) mendefinisikannya sebagai suatu tanggapan emosional pada evaluasi terhadap pengalaman konsumsi suatu produk atau jasa. Engel, ett al (1990) menyatakan bahwa kepuasan pelanggan merupakan evaluasi purna beli dimana alternatif yang dipilih sekurang-kurangnya sama atau melampaui harapan pelanggan, sedangkan ketidakpuasan timbul apabila hasil (outcome) tidak memenuhi harapan (Tjiptono, 2001 :24). Dengan demikian dapat diartikan bahwa kepuasan konsumen (nilai harapan) dengan situasi yang diberikan perusahaan di dalam usaha memenuhi harapan konsumen.

Soelasih (2004: hal 86) mengemukakan bahwa :

a. Nilai harapan $=$ nilai persepsi konsumen puas.

b. Nilai harapan < nilai persepsi maka konsumen sangat puas.

c. Nilai harapan $>$ nilai persepsi maka konsumen tidak puas. 


\section{Pengukuran Kepuasan Pelanggan}

Kotler, et al (2004) mengidentifikasi empat metode untuk mengukur kepuasan pelanggan, yaitu :

1. Sistem keluhan dan saran

Setiap organisasi yang berorientasi pada pelanggan (customer-oriented) perlu menyediakan kesempatan dan akses yang mudah dan nyaman bagi para pelanggannya guna menyampaikan saran, kritik, pendapat, dan keluhan mereka. Media yang digunakan bisa berupa kotak saran yang ditempatkan di lokasi-lokasi strategis (yang mudah dijangkau atau sering dilewati pelanggan), kartu komentar (yang bisa diisi langsung maupun yang dikirim via pos kepada perusahaan), saluran telepon khusus bebas website, dan lain-lain.

2. Ghost shopping

Salah satu cara memperoleh gambaran mengenai kepuasan pelanggan adalah dengan mempekerjakan beberapa orang ghost shopper untuk berperan atau berpura-pura sebagai pelanggan potensial produk perusahaan dan pesaing.

3. Lost customer analysis

Sedapat mungkin perusahaan menghubungi para pelanggan yang telah berhenti membeli atau yang telah pindah pemasok agar dapat memahami mengapa hal itu terjadi dan supaya dapat mengambil kebijakan perbaikan atau penyempurnaan selanjutnya

4. Survei kepuasan pelanggan

Survei bisa dilakukan melalui pos, telepon, email, websites, maupun wawacara langsung.

\section{Kualitas Pelayanan dan Kepuasan Nasabah}

Kata kualitas memiliki banyak definisi yang berbeda dan bervariasi mulai dari yang konvensional hingga yang lebih strategis. Definisi konvensional dari kualitas biasanya menggambarkan karakteristik suatu produk seperti; kinerja (performance), keandalan (reliability), mudah dalam penggunaan (easy of use), dan sebagainya. Menurut Hartono (2006) kualitas pelayanan yang meliputi reliability, responsiveness, empaty, assurance, tangible baik secara simultan maupun secara parsial kualitas pelayanan mempunyai pengaruh signifikan terhadap kepuasan nasabah PT. Bank Central Asia (BCA) Tbk Cabang Undaan Surabaya merupakan salah satu penyedia jasa dalam hal pelayanan di bidang perbankan di Surabaya, berusaha semaksimalkan mungkin memberikan pelayanan dan kemudahan kepada para pemakai jasa yang membutuhkannya, berusaha untuk meningkatkan pelayanan, kemudahan, dan fasilitas-fasilitas yang lebih baik untuk kepuasan pemakai jasa (nasabah).

Penelitian ini menggunakan model konseptual lima dimensi kualitas pelayanan yang diukur yaitu Tangibles, Reliability, Assurance, Responsiveness, dan Empathy (Dermawan Wibisono, 2006 : 95). Model tersebut memperlihatkan bahwa tingkat kepuasan secara keseluruhan dipengaruhi oleh kepuasan terhadap atribut kelima faktor tersebut, dan kepuasan akan tercapai apabila ada kesesuaian antara tingkat kepentingan dengan kinerja atau kepuasan para nasabah. Dalam penelitian ini menekankan pada beberapa variabel kualitas pelayanan yang berpengaruh terhadap kepuasan nasabah dalam memanfaatkan fasilitas pelayanan di bidang perbankan di PT. Bank Central Asi (BCA) Tbk Cabang Undaan 
Surabaya. Secara konseptual keterkaitan antara lima dimensi kualitas layanan yang diharapkan pelanggan (nasabah) dan hal-hal yang mempengaruhi pelanggan dalam menilai kualitas layanan itu sendiri dapat diilustrasikan seperti pada Gambar 1.

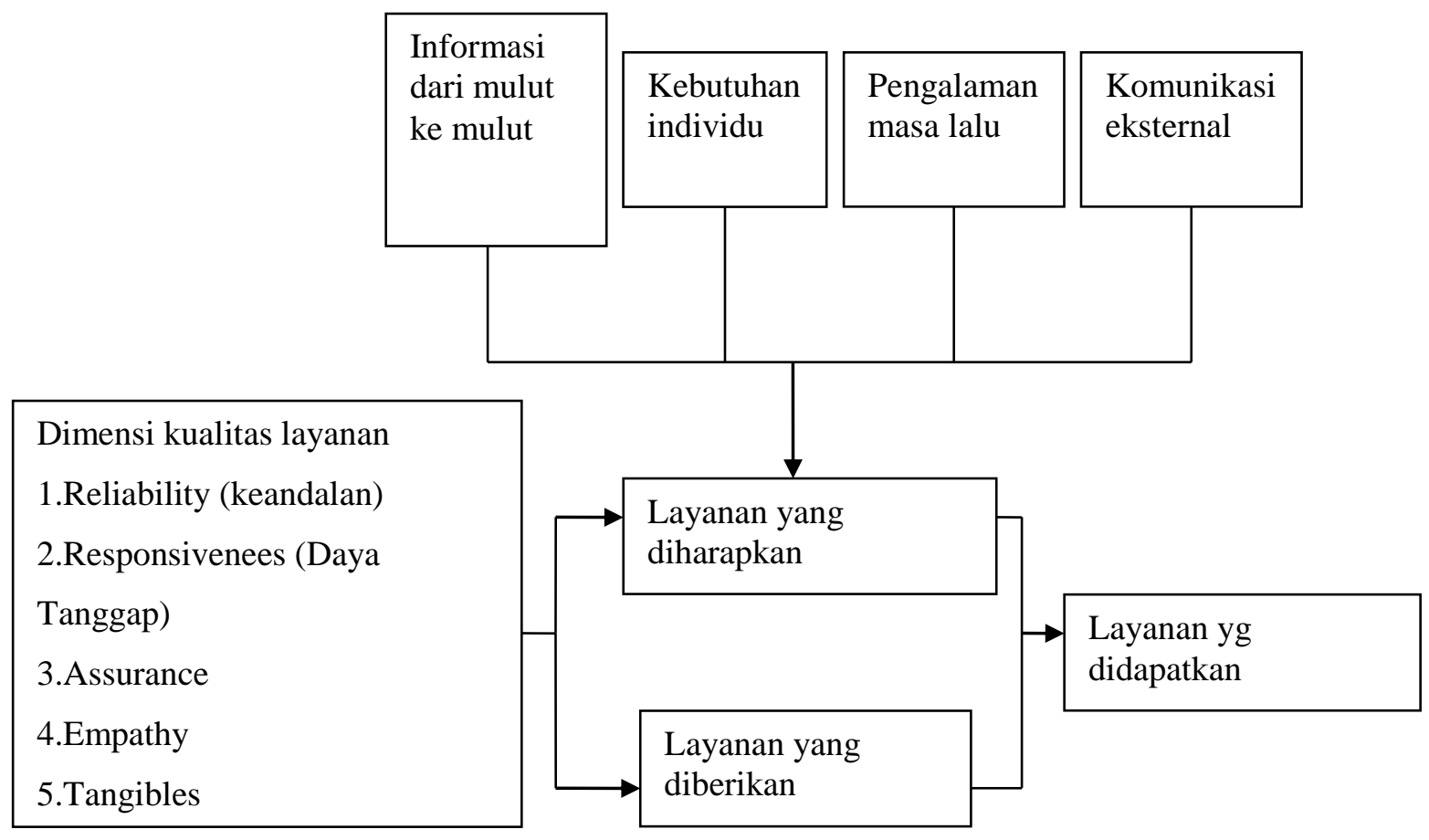

Sumber: Wibisono (2006)

\section{Gambar 1. Dimensi kualitas layanan dan penilaian kualitas layanan}

Pada dasarnya, dalam menilai kualitas layanan yang diberikan perusahaan, pelanggan akan mengkombinasikan antara informasi dari mulut ke mulut, kebutuhan masing - masing individu secara spesifik, pengalaman masa lalu, dan informasi yang merupakan hasil dari komunikasi eksternal dengan pihak-pihak lain sehingga timbullah layanan yang diharapkan oleh pelanggan (nasabah). Layanan yang diharapkan oleh pelanggan (nasabah) dikombinasikan dengan layanan yang diberikan oleh perusahaan akan menghasilkan layanan yang didapatkan oleh pelanggan (nasabah). Setelah nasabah mendapatkan pelayanan dari perusahaan maka apabila kualitas pelayanan yang diberikan sesuai atau melebihi harapan nasabah maka nasabah tersebut akan merasa puas dalam melakukan transaksi, apabila nasabah tersebut sudah merasa puas dengan pelayanan yang telah diberikan oleh perusahaan, maka akan terciptalah loyalitas pelanggan.

Pelanggan adalah asset terpenting yang dimiliki perusahaan, berbagai upaya telah dilakukan perusahaan untuk memuaskan pelanggannya. Tolak ukur suksesnya sebuah perusahaan terletak pada besarnya jumlah pelanggan yang diperolehnya. Apabila suatu perusahaan dapat memberikan kualitas pelayanan yang bagus kepada para pelanggan atau nasabahnya, maka pelanggan tersebut 
akan merasakan kepuasan karena disamping kebutuhan produk yang mereka butuhkan terpenuhi tetapi mereka juga mendapatkan pelayanan yang baik, dengan semakin besarnya kepuasan yang dirasakan oleh pelanggan maka otomatis para pelanggan atau nasabah tersebut akan semakin loyal kepada perusahaan.

Perusahaan dengan tingkat loyalitas pelanggan yang tinggi telah memperoleh tingkat loyallitas staf yang tinggi, tidak mungkin membangun loyalitas pelanggan yang kuat dengan staf yang selalu berganti-ganti (Nina Rahmayanty: Manajemen Pelayanan Prima, 2010:69). Seorang pelanggan yang loyal, sudah pasti adalah pelanggan yang puas. Hal seperti inilah yang mendorong perusahaan mengembangkan teknik untuk meningkatkan kepuasan pelanggan demi mencapai pelanggan yang loyal. Diharapkan perusahaan dapat membentuk suatu komunitas pelanggan yang loyal, sehingga dapat mencapai tingkatan pelanggan yang lebih tinggi lagi. Berdasarkan penjelasan tersebut, bisa disimpulkan bahwa Kualitas pelayanan yang meliputi variabel Responsiveness, Tangibles, Empathy, Assurance, dan Reliability secara simultan dan secara parsial berpengaruh terhadap kepuasan nasabah. Atas dasar tersebut, hipotesis yang diajukan adalah :

$\mathbf{H}_{1}$ : Kualitas pelayanan yang meliputi variabel Responsiveness, Tangibles, Empathy, Assurance, dan Reliability secara simultan berpengaruh terhadap kepuasan nasabah di PT. Bank Central Asia (BCA) Tbk Cabang Undaaan Surabaya.

$\mathbf{H}_{2}$ : Kualitas pelayanan yang meliputi variabel Responsiveness, Tangibles, Empathy, Assurance, dan Reliability secara parsial berpengaruh terhadap kepuasan nasabah di PT. Bank Central Asia (BCA) Tbk Cabang Undaaan Surabaya.

\section{METODE PENELITIAN}

\section{Populasi dan Sampel Penelitian}

Populasi yang digunakan dalam penelitian ini adalah nasabah pada PT. Bank Central Asia (BCA) Tbk Cabang Undaan Surabaya sejumlah 3.972 nasabah. Terdiri dari 3.942 penabung. Nasabah ini khusus yang ada di kantor Cabang. Pengambilan sampel pada penelitian ini menggunakan sampel berstrata (Stratified Random Sampling). Pengambilan sampel berstrata (stratified random sampling) dilakukan pada suatu populasi yang terbagi atas beberapa strata atau sub kelompok dan dari masing-masing sub kelompok diambil sampel-sampel terpisah. Sampel yang diambil adalah penabung yang datang sendiri maupun yang datang diwakilkan oleh pegawai atau karyawannya. Apabila yang datang karyawannya maka yang menjadi sampel adalah karyawan atau pegawainya, karena mereka yang bisa langsung merasakan pelayanan dari para karyawan Bank BCA.

Tabel 1. Jumlah Populasi Penelitian Berdasarkan Besarnya Tabungan

\begin{tabular}{lc}
\hline \multicolumn{1}{c}{ Jumlah besarnya tabungan $($ Rp) } & Jumlah nasabah \\
\hline $\mathrm{X}<\mathrm{Rp} 1,000,000$ & 788 \\
$\mathrm{Rp} 1,000,000 \leq \mathrm{X}<\mathrm{Rp} 10,000,000$ & 592 \\
$\mathrm{Rp} 10,000,000 \leq \mathrm{X}<\mathrm{Rp} \mathrm{100,000,000}$ & 1577 \\
$\mathrm{Rp} 100,000,000 \leq \mathrm{X}<\mathrm{Rp} \mathrm{1,000,000,000}$ & 788 \\
$\mathrm{X} \geq \operatorname{Rp~} 1,000,000,000 \quad$ Jumlah & 197 \\
& $\mathrm{~N}=3942$ \\
\hline
\end{tabular}


Ukuran sampel dari suatu populasi dapat ditentukan dengan menggunakan rumus Slovin (1960) yang dikutip Sevilla (1994) seperti berikut:

$\mathrm{n}=\frac{N}{1+N e^{2}}$

Dimana :

$\mathrm{n} \quad=\quad$ Ukuran sampel

$N=$ Ukuran populasi

e $=$ Persen kelonggaran ketidaktelitian karena kesalahan pengambilan sampel yang masih dapat ditolerir atau diinginkan.

Jadi berdasarkan rumus diatas, sampel dalam penelitian ini sebesar 364 responden.

Tabel 2. Jumlah Sampel Berdasarkan Besarnya Tabungan

\begin{tabular}{|c|c|}
\hline Jumlah besarnya tabungan (Rp) & Jumlah nasabah \\
\hline $\mathrm{X}<\mathrm{Rp} 1,000,000$ & 73 \\
\hline $\operatorname{Rp} 1,000,000 \leq X<\operatorname{Rp} 10,000,000$ & 55 \\
\hline $\operatorname{Rp} 10,000,000 \leq X<\operatorname{Rp} 100,000,000$ & 145 \\
\hline $\operatorname{Rp} 100,000,000 \leq X<\operatorname{Rp} 1,000,000,000$ & 73 \\
\hline$X \geq \operatorname{Rp} 1,000,000,000$ & 18 \\
\hline Jumlah & $n=364$ \\
\hline
\end{tabular}

\section{Definisi Operasional Variabel \\ Kualitas Pelayanan}

Kualitas pelayanan adalah suatu kegiatan pelayanan yang diberikan kepada pelanggan sesuai dengan prinsip : lebih mudah, lebih baik, cepat, tepat, akurat, ramah, sesuai dengan harapan pelanggan. Peneliti menggunakan lima dimensi kualitas pelayanan (Dermawan Wibisono,ph.D, 2006:95) antara lain meliputi :

a. Responsiveness

Responsiveness (daya tanggap), yaitu kemampuan dari para karyawan PT. Bank Central Asia (BCA) Tbk Cabang Undaan Surabaya untuk membantu para nasabah, dan memberikan pelayanan dengan cepat dan tanggap sesuai dengan kebutuhan.

b. Tangibles

Tangibles, yaitu fasilitas fisik penyedia jasa, termasuk peralatan, perlengkapan atau tenaga administrasi, penampilan karyawan, sarana komunikasi, dan bukti fisik fasilitas yang ada di PT. Bank Central Asia (BCA) Tbk Cabang Undaan Surabaya.

c. Empathy

Empathy, yaitu peduli, mampu memberi perhatian pribadi pada setiap nasabah, meliputi kemudahan dalam melakukan hubungan, komunikasi yang baik, perhatian pribadi, dan pemahaman atas kebutuhan nasabah di PT. Bank Central Asia (BCA) Tbk Cabang Undaan Surabaya. 


\section{d. Assurance}

Assurance, yaitu mencakup jaminan dan kemampuan, kesopanan dan sifat yang dapat dipercaya yang dimiliki para karyawan PT. Bank Central Asia Cabang Undaan Surabaya, sehingga menimbulkan kepercayaan dan keyakinan nasabah.

\section{e. Reliability}

Reliability (kehandalan), yaitu kemampuan dalam memberikan pelayanan yang disajikan dengan segera, akurat, tepat waktu sesuai dengan yang dijanjikan, dan memuaskan.

Dari kelima variabel tersebut (Responsiveness, Tangibles, Empathy, Assurance, Reliability) yang diukur adalah indikator dari masing-masing variabel. Dari indikator dapat dibuat pernyataan melalui quisioner. Dari jawaban quisioner tersebut diambil nilai rata-ratanya dari masing-masing indikator.

\section{Kepuasan Nasabah}

Kepuasan nasabah adalah hasil perbandingan antara persepsi dengan harapan selama nasabah melakukan transaksi di PT. Bank Central Asia (BCA) Tbk Cabang Undaan Surabaya. Untuk tingkat kepuasan nasabah dapat diukur dengan indikator antara lain : mudah melakukan transaksi, ketepatan pelayanan, keterbukaan informasi, komunikasi dengan nasabah. Dari indikator dapat dibuat pernyataan melalui quisioner. Dari jawaban quisioner tersebut diambil nilai rata ratanya dari masing - masing indikator.

Tabel 3. Variabel dan Indikator Yang Mempengaruhi Kepuasan Nasabah di PT. Bank Central Asia tbk Cabang Undaan Surabaya

\begin{tabular}{|c|c|c|}
\hline $\begin{array}{l}\mathbf{N} \\
\mathbf{0}\end{array}$ & Variabel & Indikator Variabel \\
\hline 1 & $\begin{array}{l}\text { Responsiveness } \\
\left(\mathrm{X}_{1}\right)\end{array}$ & $\begin{array}{l}\text { Penanganan cepat bagi nasabah baru }\left(\mathrm{x}_{1.1}\right) \\
\text { Prosedur pemeriksaan yang mudah }\left(\mathrm{x}_{1.2}\right) \\
\text { Ramah dan sopan dalam memberikan pelayanan }\left(\mathrm{x}_{1.3}\right) \\
\text { Cepat tanggap terhadap keluhan nasabah }\left(\mathrm{x}_{1.4}\right) \\
\text { Mampu menanmkan kepercayaan pada nasabah }\left(\mathrm{x}_{1.5}\right)\end{array}$ \\
\hline 2 & $\begin{array}{l}\text { Tangibles } \\
\left(\mathrm{X}_{2}\right)\end{array}$ & $\begin{array}{l}\text { Kenyamanan ruang tunggu }\left(\mathrm{x}_{2.1}\right) \\
\text { Kondisi peralatan dan ruangan memadai }\left(\mathrm{x}_{2.2}\right) \\
\text { Lokasi bank mudah dijangkau }\left(\mathrm{x}_{2.3}\right) \\
\text { Terdapat fasilitas umum yang baik dan bersih }\left(\mathrm{x}_{2.4}\right) \\
\text { Jumlah tenaga karyawan memadai }\left(\mathrm{x}_{2.5}\right)\end{array}$ \\
\hline 3 & $\begin{array}{l}\text { Empathy } \\
\left(\mathrm{X}_{3}\right)\end{array}$ & $\begin{array}{l}\text { Mampu memberi perhatian/kesan yang baik }\left(\mathrm{x}_{3.1}\right) \\
\text { Bersedia mendengar keluhan dengan sabar }\left(\mathrm{x}_{3.2}\right) \\
\text { Mampu menjaga intensitas komunikasi kepada nasabah dengan baik }( \\
\left.\mathrm{x}_{3.3}\right) \\
\text { Mampu memahami kebutuhan nasabah }\left(\mathrm{x}_{3.4}\right)\end{array}$ \\
\hline 4 & $\begin{array}{l}\text { Assurance } \\
\left(\mathrm{X}_{4}\right)\end{array}$ & $\begin{array}{l}\text { Dapat menciptakan suasana nyaman dan aman }\left(\mathrm{x}_{4.1}\right) \\
\text { Komunikasi dengan bahasa yang mudah dipahami }\left(\mathrm{x}_{4.2}\right) \\
\text { Dapat menanamkan nilai-nilai kesopanan pada nasabah/keluarganya ( } \\
\left.\mathrm{x}_{4.3}\right) \\
\text { Terdapat petunjuk arah sehingga memudahkan nasabah dalam mencari }\end{array}$ \\
\hline
\end{tabular}




\begin{tabular}{lll}
\hline & & pelayanan $\left(\mathrm{x}_{4.4}\right)$ \\
& & Pelayanannya dapat memenuhi harapan nasabah $\left(\mathrm{x}_{4.5}\right)$ \\
& Menangani nasabah cepat dan profesional $\left(\mathrm{x}_{5.1}\right)$ \\
& & Transparasi biaya/tarif $\left(\mathrm{x}_{5.2}\right)$ \\
$5 \quad$ & Reliability & Memberlakukan nasabah secara adil $\left(\mathrm{x}_{5.3}\right)$ \\
& $\left(\mathrm{X}_{5}\right)$ & Pelayanannya sesuai dengan yang diharapkan $\left(\mathrm{x}_{5.4}\right)$ \\
& & Pelayanan yang benar pada nasabah baru $\left(\mathrm{x}_{5.5}\right)$ \\
& & Mudah melakukan transaksi $\left(\mathrm{Y}_{1.1}\right)$ \\
& Kepuasan & Ketepatan Pelayanan $\left(\mathrm{Y}_{1.2}\right)$ \\
& Nasabah & Keterbukaan Informasi $\left(\mathrm{Y}_{1.3}\right)$ \\
& $\left(\mathrm{Y}_{1}\right)$ & Komunikasi Dengan Nasabah $\left(\mathrm{Y}_{1.4}\right)$ \\
\hline
\end{tabular}

Variabel-variabel tersebut diatas nantinya digunakan untuk menyusun instrumen pertanyaan atau kuesioner dengan scoring model Likert (skala likert) yang diisi oleh responden. Skala likert digunakan untuk mengukur sikap, pendapat, dan persepsi seseorang atau sekelompok orang tentang fenomena sosial. Dengan skala likert, maka variabel yang akan diukur dijabarkan menjadi indikator variabel. Kemudian indikator tersebut dijadikan sebagai titik tolak untuk menyusun item-item instrumen yang dapat berupa pernyataan atau pertanyaan. Untuk menghindari jawaban cukup setuju, ragu-ragu atau netral maka skala likert yang digunakan adalah empat skala. Adapun skala likert yang digunakan dibagi menjadi empat skala yaitu : sangat tidak setuju (STS), tidak setuju (TS), setuju (S), dan sangat setuju (SS). Untuk analisis secara kuantitatif, maka alternatif jawaban tersebut diberi skor dari nilai 1 sampai 4 dengan rincian (1) sangat tidak setuju, (2) tidak setuju, (3) setuju, (4) sangat setuju.

\section{Teknik Analisis Data}

Teknik analisis data yang digunakan adalah regresi linier berganda. Berikut ini adalah persamaannya :

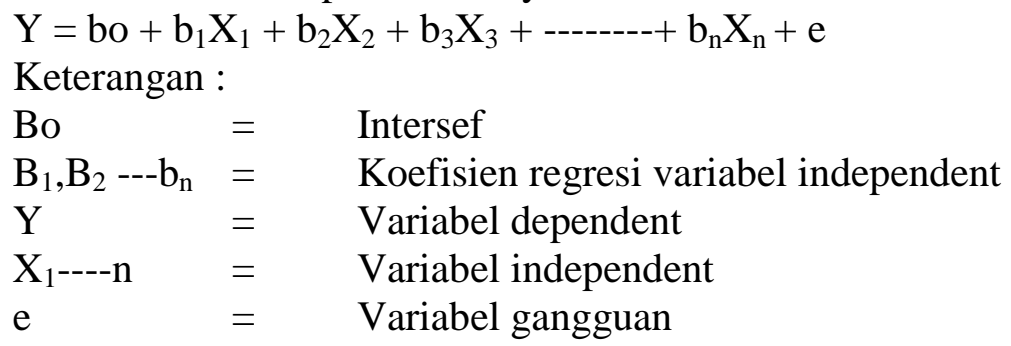

Pengujian hipotesis dilakukan secara simultan atau Uji F dan secara parsial atau uji t. Uji F bertujuan untuk mengetahui besarnya pengaruh kualitas pelayanan yang meliputi variabel Responsiveness, Tangibles, Empathy, Assurance, dan Reliability secara simultan terhadap kepuasan nasabah. Sedangkan Uji t bertujuan untuk mengetahui besarnya pengaruh kualitas pelayanan yang meliputi variabel Responsiveness, Tangibles, Empathy, Assurance, dan Reliability secara parsial terhadap kepuasan nasabah. 


\section{HASIL DAN PEMBAHASAN}

Pada bagian ini akan dijelaskan deskripsi setiap variable penelitian yaitu dengan menjelaskan nilai rata-rata masing-masing indikator yang membentuk variable tersebut dengan tujuan mengetahui tanggapan responden tentang indikator-indikator yang membentuk variable responsiveness $\left(\mathrm{X}_{1}\right)$, tangibles $\left(\mathrm{X}_{2}\right)$, empathy $\left(\mathrm{X}_{3}\right)$, assurance $\left(\mathrm{X}_{4}\right)$, reliability $\left(\mathrm{X}_{5}\right)$ dan kepuasan nasabah $(\mathrm{Y})$.

Tabel 4. Nilai Rata-Rata Indikator Responsiveness $\left(\mathbf{X}_{1}\right)$

\begin{tabular}{llr}
\hline No & \multicolumn{1}{c}{ Indikator } & Rata-rata \\
\hline & $\begin{array}{l}\text { Begitu sampai di bank ini sebagai nasabah maupun yang bukan } \\
\text { nasabah BCA, petugas segera membantu dalam melakukan }\end{array}$ & 3,530 \\
& $\begin{array}{l}\text { transaksi } \\
2\end{array}$ & $\begin{array}{l}\text { Mudah bagi saudara untuk mengikuti prosedur untuk melakukan } \\
\text { transaksi }\end{array}$ \\
3 & Petugas memberikan pelayanan dengan ramah dan sopan & 3,536 \\
4 & Petugas cepat dan tanggap dalam menghadapi setiap persoalan dan & 3,541 \\
5 & keluhan dari nasabah & 3,538 \\
& Petugas mampu menanamkan kepercayaan kepada nasabah & 3,533 \\
Rata-Rata Responsiveness & 3,536 \\
\hline
\end{tabular}

Sumber : data diolah, 2014

Nilai rata-rata responsiveness sebesar 3,536 menunjukkan ketanggapan yang dilakukan oleh petugas BCA cukup tinggi. Ketanggapan ini ditunjukkan dengan memberikan layanan dengan ramah dan sopan, cepat dan tanggap dalam menghadapi setiap persoalan dan keluhan dari nasabah dan memberikan kemudahan untuk mengikuti prosedur dalam melakukan transaksi. Ketanggapan inilah yang mampu menanamkan kepercayaan kepada nasabah. Ketanggapan yang dilakukan oleh petugas layanan sesuai dengan standar layanan di PT Bank Central Asia (BCA) yaitu prinsip "sigap" dengan memberikan respon dengan cepat sesuai dengan service level yang diharapkan atas permintaan atau keluhan yang diterima.

Tabel 5. Nilai Rata-Rata Indikator Tangibles $\left(\mathbf{X}_{2}\right)$

\begin{tabular}{llc}
\hline No & \multicolumn{1}{c}{ Indikator } & Rata-rata \\
\hline 1 & Ruang tunggu yang disediakan terasa nyaman & 3,396 \\
2 & Kondisi peralatan dan ruangan yang ada memadai & 3,387 \\
3 & Lokasi mudah dijangkau oleh para nasabah & 3,390 \\
4 & Terdapat fasilitas umum (parkir,toilet) yang baik dan bersih & 3,393 \\
5 & Jumlah karyawan memadai sesuai dengan masing-masing tugasnya & 3,398 \\
& Rata-Rata Tangibles & 3,393 \\
\hline
\end{tabular}

Sumber : data diolah, 2014

Fasilitas fisik yang disediakan oleh PT. Bank Central Asia (BCA) Cabang Undaan cukup baik (nilai rata-rata 3,393) berupa lokasi mudah dijangkau oleh para nasabah, ruang tunggu cukup nyaman, terdapat fasilitas umum (parkir,toilet) yang baik dan bersih dan kondisi peralatan dan ruangan yang ada memadai dengan jumlah karyawan sesuai dengan masing-masing tugas. Hal ini sesuai 
dengan standar layanan BCA pada prinsip "menarik" yaitu dengan memelihara dan menjaga kerapian dan kebersihan tempat kerja serta perlengkapan kerja demi terciptanya suasana dan lingkungan kerja yang memberikan kenyamanan dalam bekerja dan mendukung produktivitas kerja secara optimal.

Tabel 6. Nilai Rata-Rata Indikator Empathy $\left(\mathbf{X}_{3}\right)$

\begin{tabular}{llc}
\hline No & \multicolumn{1}{c}{ Indikator } & Rata-rata \\
\hline 1 & $\begin{array}{l}\text { Petugas mampu memberikan perhatian/kesan yang baik terhadap } \\
\text { nasabah }\end{array}$ & 3,489 \\
2 & $\begin{array}{l}\text { Petugas selalu bersedia mendengarkan setiap keluhan/ } \\
\text { permasalahan nasabah dalam melakukan transaksi }\end{array}$ & 3,484 \\
3 & $\begin{array}{l}\text { Petugas menjaga intensitas komunikasi kepada nasabah dengan } \\
\text { baik }\end{array}$ & 3,492 \\
4 & $\begin{array}{l}\text { Petugas mampu memahami kebutuhan para nasabahnya } \\
\text { Rata-Rata Empathy }\end{array}$ & 3,486 \\
\hline
\end{tabular}

Empati yang diberikan oleh petugas BCA cukup tinggi (nilai rata-rata 3,488 ) dilakukan dengan cara memberikan perhatian terhadap nasabah dnegan mendengarkan setiap keluhan nasabah dalam melakukan transaksi. Selain itu para petugas BCA mampu menjaga intensitas komunikasi kepada nasabah dengan baik melalui pemahaman terhadap kebutuhan pada nasabah. Empati dalam standar layanan BCA diterapkan pada prinsip "antusias" yaitu memecahkan masalah, memberikan solusi dan rekomendasi dengan lebih kreatif, inovatif dan efektif.

Tabel 7. Nilai Rata-Rata Indikator Assurance $\left(\mathbf{X}_{4}\right)$

\begin{tabular}{|c|c|c|}
\hline No & Indikator & Rata-rata \\
\hline 1 & Petugas dapat menciptakan suasana nyaman kepada nasabah & 3,467 \\
\hline 2 & $\begin{array}{l}\text { Petugas mampu berkomunikasi dengan bahasa yang mudah } \\
\text { dipahami }\end{array}$ & 3,451 \\
\hline 3 & $\begin{array}{l}\text { Petugas dapat menerapkan nilai-nilai kesopanan kepada nasabah / } \\
\text { keluarganya }\end{array}$ & 3,456 \\
\hline 4 & $\begin{array}{l}\text { Tersedianya petunjuk arah sehingga memudahkan nasabah dalam } \\
\text { mencari pelayanan }\end{array}$ & 3,464 \\
\hline \multirow[t]{2}{*}{5} & $\begin{array}{l}\text { Pelayanan yang diberikan petugas dapat memenuhi harapan para } \\
\text { nasabah }\end{array}$ & 3,459 \\
\hline & Rata-Rata Assurance & 3,459 \\
\hline
\end{tabular}

Sumber : data diolah, 2014

Assurance dilakukan petugas BCA dengan menciptakan suasana nyaman kepada nasabah, mampu berkomunikasi dengan bahasa yang mudah dipahami, hal ini ditujukan untuk memenui harapan nasabah. Assurance diterapkan melalui standar layanan BCA dengan prinsip "ramah" yaitu dengan memperlihatkan keramahan yang tulus saat berinteraksi. 
Tabel 8. Nilai Rata-Rata Indikator Reliability $\left(\mathbf{X}_{5}\right)$

\begin{tabular}{llc}
\hline No & \multicolumn{1}{c}{ Indikator } & Rata-rata \\
\hline 1 & Petugas mampu menangani nasabah dengan cepat dan profesional & 3,448 \\
2 & Informasi tentang biaya/tarif diberitahukan terlebih dahulu dengan & 3,445 \\
3 & jelas oleh petugas & 3,442 \\
4 & Memberlakukan nasabah secara adil & 3,440 \\
4 & Petugas selalu berusaha memberikan pelayanan yang terbaik & 3,437 \\
5 & Memberikan pelayanan yang benar kepada nasabah baru & 3,442 \\
\hline
\end{tabular}

Sumber : data diolah, 2014

Reliability merupakan keandalan yang ditunjukkan oleh petugas BCA sangat baik (nilai rata-rata 3,442) dengan kemampuan menangani nasabah dengan cepat dan profesional, memberikan pelayanan yang terbaik sesuai dengan yang diharapkan oleh para nasabah dan memberikan pelayanan yang benar kepada nasabah baru.

Tabel 9. Nilai Rata-Rata Indikator Kepuasan Nasabah (Y)

\begin{tabular}{llc}
\hline No & \multicolumn{1}{c}{ Indikator } & Rata-rata \\
\hline 1 & $\begin{array}{l}\text { Petugas selalu memberikan kemudahan dan solusi terbaik kepada } \\
\text { nasabah dalam bertransaksi }\end{array}$ & 3,673 \\
\hline 2 & $\begin{array}{l}\text { Petugas mampu melayani transaksi nasabah dengan cepat, tepat, dan } \\
\text { akurat }\end{array}$ & 3,629 \\
\hline 3 & $\begin{array}{l}\text { Petugas selalu konfirmasi terlebih dahulu apabila ada biaya - biaya } \\
\text { yang harus dibayar oleh nasabah }\end{array}$ & 3,637 \\
\hline 4 & $\begin{array}{l}\text { Petugas berkomunikasi dengan nasabah dengan menggunakan } \\
\text { bahasa indonesia yang baik, sopan, dan ramah }\end{array}$ & 3,643 \\
\hline & Rata-Rata Kepuasan Nasabah & 3,646 \\
\hline Sumber : data diolah, 2014
\end{tabular}

Kualitas layanan yang diberikan oleh petugas BCA cukup baik dapat memberikan kepuasan nasabah atas kemudahan dan solusi terbaik kepada nasabah dalam bertransaksi, kepuasan akan kemampuan melayani transaksi nasabah dengan cepat, tepat, dan akurat. Nasabah tidak hanya puas dengan layanan yang diberikan, namun juga puas dengan komunikasi yang dilakukan oleh petugas dengan baik, sopan, dan ramah.

\section{Uji Validitas dan Reliabilitas}

Alat ukur yang dipergunakan dalam penelitian ini berupa daftar pertanyaan, yang terdiri dari item-item atau butir-butir pertanyaan yang dirancang dan disusun untuk memperoleh data variabel-variabel penelitian yang berasal dari jawaban responden. Dari penyebaran kuesioner, yang dianggap lengkap dan memenuhi syarat sebanyak 364 kuesioner. Pada penelitian ini, yang diuji validitas dan reliabilitasnya adalah variabel responsiveness $\left(\mathrm{X}_{1}\right)$, tangibles $\left(\mathrm{X}_{2}\right)$, empathy $\left(\mathrm{X}_{3}\right)$, assurance $\left(\mathrm{X}_{4}\right)$, reliability $\left(\mathrm{X}_{5}\right)$ dan kepuasan nasabah $(\mathrm{Y})$. 


\section{Uji Validitas dan Reliabilitas Responsiveness $\left(\mathrm{X}_{1}\right)$}

Berdasarkan tabel 10, nilai signifikansi untuk koefisien korelasi antara setiap item dengan total item lebih kecil dari taraf signifikansi yang ditetapkan $(\alpha)$ yaitu 0,05 . Hal ini dapat dikatakan bahwa jawaban responden pada seluruh item adalah valid. Nilai koefisien reliabilitasnya sebesar 0,6317 lebih besar dari 0,6 berarti seluruh item tersebut diatas sudah reliabel untuk menjelaskan variabel responsiveness.

Tabel 10. Uji Validitas dan Reliabilitas Responsiveness $\left(X_{1}\right)$

\begin{tabular}{cccc}
\hline Variabel & $\begin{array}{c}\text { Koefisien } \\
\text { Korelasi }\end{array}$ & Signifikansi & Keterangan \\
\hline X1.1 & 0,5415 & $3,997.10^{-029}$ & Valid \\
X1.2 & 0,5297 & $1,018.10^{-027}$ & Valid \\
X1.3 & 0,5057 & $4,962.10^{-025}$ & Valid \\
X1.4 & 0,5261 & $2,674.10^{-027}$ & Valid \\
X1.5 & 0,4836 & $9,898.10^{-023}$ & Valid \\
Reliabilitas = $\mathbf{0 , 6 3 1 7}$ & & & \\
\hline S
\end{tabular}

Sumber: data diolah, 2014

\section{Uji Validitas dan Reliabilitas Tangibles $\left(\mathrm{X}_{2}\right)$}

Berdasarkan tabel 11, nilai signifikansi untuk koefisien korelasi antara setiap item dengan total item lebih kecil dari taraf signifikansi yang ditetapkan $(\alpha)$ yaitu 0,05 . Hal ini dapat dikatakan bahwa jawaban responden pada seluruh item adalah valid. Nilai koefisien reliabilitasnya sebesar 0,6337 lebih besar dari 0,6 berarti seluruh item tersebut diatas sudah reliabel untuk menjelaskan variabel tangibles.

Tabel 11. Uji Validitas dan Reliabilitas Tangibles $\left(\mathbf{X}_{2}\right)$

\begin{tabular}{cccc}
\hline Variabel & $\begin{array}{c}\text { Koefisien } \\
\text { Korelasi }\end{array}$ & Signifikansi & Keterangan \\
\hline X2.1 & 0,3596 & $1,493.10^{-012}$ & Valid \\
X2.2 & 0,5208 & $1,072.10^{-026}$ & Valid \\
X2.3 & 0,5788 & $6,162.10^{-034}$ & Valid \\
X2.4 & 0,6089 & $2,597.10^{-038}$ & Valid \\
X2.5 & 0,5342 & $3,020.10^{-028}$ & Valid \\
Reliabilitas $=\mathbf{0 , 6 3 3 7}$ & & & \\
\hline
\end{tabular}

Sumber : data diolah, 2014

Uji Validitas dan Reliabilitas Empathy $\left(\mathbf{X}_{3}\right)$

Berdasarkan tabel 12, nilai signifikansi untuk koefisien korelasi antara setiap item dengan total item lebih kecil dari taraf signifikansi yang ditetapkan $(\alpha)$ yaitu 0,05 . Hal ini dapat dikatakan bahwa jawaban responden pada seluruh item adalah valid. Nilai koefisien reliabilitasnya sebesar 0,6217 lebih besar dari 0,6 
berarti seluruh item tersebut diatas sudah reliabel untuk menjelaskan variabel empathy.

Tabel 12. Uji Validitas dan Reliabilitas Empathy $\left(\mathbf{X}_{3}\right)$

\begin{tabular}{cccc}
\hline Variabel & $\begin{array}{c}\text { Koefisien } \\
\text { Korelasi }\end{array}$ & Signifikansi & Keterangan \\
\hline X3.1 & 0,5094 & $1,985.10^{-025}$ & Valid \\
X3.2 & 0,6151 & $2,864.10^{-039}$ & Valid \\
X3.3 & 0,5649 & $4,468.10^{-032}$ & Valid \\
X3.4 & 0,4954 & $6,162.10^{-024}$ & Valid \\
Reliabilitas $=\mathbf{0 , 6 2 1 7}$ & & & \\
\hline
\end{tabular}

Sumber : data diolah, 2014

\section{Uji Validitas dan Reliabilitas Assurance $\left(\mathrm{X}_{4}\right)$}

Berdasarkan tabel 13, nilai signifikansi untuk koefisien korelasi antara setiap item dengan total item lebih kecil dari taraf signifikansi yang ditetapkan $(\alpha)$ yaitu 0,05 . Hal ini dapat dikatakan bahwa jawaban responden pada seluruh item adalah valid. Nilai koefisien reliabilitasnya sebesar 0,6224 lebih besar dari 0,6 berarti seluruh item tersebut diatas sudah reliabel untuk menjelaskan variabel assurance.

Tabel 13. Uji Validitas dan Reliabilitas Assurance $\left(\mathbf{X}_{4}\right)$

\begin{tabular}{cccc}
\hline Variabel & $\begin{array}{c}\text { Koefisien } \\
\text { Korelasi }\end{array}$ & Signifikansi & Keterangan \\
\hline X4.1 & 0,3785 & $7,624.10^{-014}$ & Valid \\
X4.2 & 0,5405 & $6,344.10^{-029}$ & Valid \\
X4.3 & 0,4495 & $1,670.10^{-019}$ & Valid \\
X4.4 & 0,5683 & $1,623.10^{-032}$ & Valid \\
X4.5 & 0,5207 & $1,092.10^{-026}$ & Valid \\
Reliabilitas $=\mathbf{0 , 6 2 2 4}$ & & & \\
\hline
\end{tabular}

Sumber : data diolah, 2014

\section{Uji Validitas dan Reliabilitas Reliability $\left(\mathbf{X}_{\mathbf{5}}\right)$}

Berdasarkan tabel 14, nilai signifikansi untuk koefisien korelasi antara setiap item dengan total item lebih kecil dari taraf signifikansi yang ditetapkan $(\alpha)$ yaitu 0,05 . Hal ini dapat dikatakan bahwa jawaban responden pada seluruh item adalah valid. Nilai koefisien reliabilitasnya sebesar 0,6342 lebih besar dari 0,6 berarti seluruh item tersebut diatas sudah reliabel untuk menjelaskan variabel reliability.

Tabel 14. Uji Validitas dan Reliabilitas Reliability $\left(X_{5}\right)$

\begin{tabular}{cccc}
\hline Variabel & $\begin{array}{c}\text { Koefisien } \\
\text { Korelasi }\end{array}$ & Signifikansi & Keterangan \\
\hline X5.1 & 0,4766 & $4,897.10^{-022}$ & Valid \\
X5.2 & 0,5361 & $1,802.10^{-028}$ & Valid \\
\hline
\end{tabular}




\begin{tabular}{llll}
\hline X5.3 & 0,5543 & $1,063.10^{-030}$ & Valid \\
X5.4 & 0,5764 & $1,297.10^{-033}$ & Valid \\
X5.5 & 0,4773 & $4,103.10^{-022}$ & Valid \\
\hline
\end{tabular}

Reliabilitas $=0,6342$

Sumber : data diolah, 2014

\section{Uji Validitas dan Reliabilitas Kepuasan Nasabah (Y)}

Berdasarkan tabel 15 nilai signifikansi untuk koefisien korelasi antara setiap item dengan total item lebih kecil dari taraf signifikansi yang ditetapkan $(\alpha)$ yaitu 0,05 . Hal ini dapat dikatakan bahwa jawaban responden pada seluruh item adalah valid. Nilai koefisien reliabilitasnya sebesar 0,7190 lebih besar dari 0,6 berarti seluruh item tersebut diatas sudah reliabel untuk menjelaskan variabel kepuasan nasabah.

Tabel 15. Uji Validitas dan Reliabilitas Kepuasan Nasabah (Y)

\begin{tabular}{cccc}
\hline Variabel & $\begin{array}{c}\text { Koefisien } \\
\text { Korelasi }\end{array}$ & Signifikansi & Keterangan \\
\hline Y.1 & 0,4941 & $8,296.10^{-024}$ & Valid \\
Y.2 & 0,5734 & $3,334.10^{-033}$ & Valid \\
Y.3 & 0,5453 & $1,393.10^{-029}$ & Valid \\
Y.4 & 0,5455 & $1,295.10^{-029}$ & Valid \\
Reliabilitas $=\mathbf{0 , 7 1 9 0}$ & & &
\end{tabular}

Sumber : data diolah, 2014

\section{Hasil Pengujian Hipotesis}

Berdasarkan hasil perhitungan regresi linier pada tabel 16 diperoleh persamaan sebagai berikut :

$$
Y=0,0642+0,5572 X_{1}+0,4727 X_{2}+0,6468 X_{3}+0,6059 X_{4}+0,5238 X_{5}
$$

Koefisien determinasi sebesar 0,5901 menunjukkan bahwa besarnya kontribusi seluruh variabel bebas terhadap kepuasan nasabah sebesar 59,01\%, sedangkan sisanya $40,99 \%$ dipengaruhi oleh variabel lain yang tidak ada dalam persamaan. Nilai $R$ Square diperoleh hasil sebesar 0,5958 berarti bahwa masingmasing variabel bebas mampu menerangkan kepuasan nasabah sebesar 59,58 persen, sedangkan sisanya 40,42 persen dipengaruhi oleh faktor - faktor lain diluar model penelitian.

Tabel 16. Hasil Perhitungan Regresi Berganda

\begin{tabular}{lcccc}
\hline \multicolumn{1}{c}{ Variabel } & $\begin{array}{c}\text { Koefisien } \\
\text { Regresi }\end{array}$ & Beta & Prob. & Keterangan \\
\hline Responsiveness $\left(\mathrm{X}_{1}\right)$ &, 5572 &, 5900 & $5,48210^{-6}$ & Signifikan \\
Tangibles $\left(\mathrm{X}_{2}\right)$ &, 4727 &, 6254 & $2,65110^{-8}$ & Signifikan \\
Empathy $\left(\mathrm{X}_{3}\right)$ &, 6468 &, 7801 & $1,69910^{-12}$ & Signifikan \\
Assurance $\left(\mathrm{X}_{4}\right)$ &, 6059 &, 7139 & $1,73510^{-10}$ & Signifikan \\
Reliability $\left(\mathrm{X}_{5}\right)$ &, 5238 &, 6864 & $6,85310^{-9}$ & Signifikan
\end{tabular}




\begin{tabular}{lll}
\hline Konstan & $=0,0642$ & $\mathrm{R}^{2}=0,5958$ \\
F hitung & $=105,44 ;$ prob $=3,54410^{-68}$ & Adjs $^{2}=0,5901$ \\
\hline Sumber $:$ data &
\end{tabular}

Sumber : data diolah, 2014

Tabel 17. Hasil Perhitungan Pengujian Hipotesis (UJI F)

\begin{tabular}{llllll}
\hline Model & $\begin{array}{l}\text { Sum Of } \\
\text { Squares }\end{array}$ & Df & $\begin{array}{l}\text { Mean } \\
\text { Squares }\end{array}$ & F & Sig \\
\hline Regression & 20,3500 & 5 & 4,0700 & 105,4404 & $3,544 \mathrm{E}-068^{\mathrm{a}}$ \\
Residual & 13,8080 & 358 &, 0386 & & \\
Total & 34,1580 & 363 & & & \\
\hline
\end{tabular}

Sumber: data diolah, 2014

Tabel 18. Hasil Perhitungan Uji t

\begin{tabular}{ccc}
\hline Variabel & T & Sig \\
\hline Responsiveness & 4,6151 & $5,482.10^{-6}$ \\
Tangibles & 5,6896 & $2,651.10^{-8}$ \\
Empathy & 7,3153 & $1,699.10^{-12}$ \\
Assurance & 6,5740 & $1,735.10^{-10}$ \\
Reliability & 5,9374 & $6,853.10^{-9}$ \\
\hline
\end{tabular}

Sumber: data diolah, 2014

\section{PEMBAHASAN}

Berdasarkan analisis Uji $\mathrm{F}$ dalam penelitian ini menunjukkan bahwa kualitas pelayanan yang meliputi variabel Responsiveness, Tangibles, Empathy, Assurance, dan Reliability mempunyai pengaruh yang signifikan terhadap kepuasan nasabah di PT. Bank Central Asia (BCA) Tbk Cabang Undaan Surabaya. Hal ini dapat dibuktikan dari nilai $F_{\text {hitung }}(105,4404)$ lebih besar dari $\mathrm{F}_{\text {tabel }}(2,24)$ dan nilai signifikansinya sebesar $3,544.10^{-68}$ lebih kecil daripada $\alpha$ yang bernilai 0,05 . Penelitian ini sesuai dengan penelitian yang dilakukan oleh Hartono (2006) yang menyimpulkan bsik secara simultan maupun secara parsial kualitas pelayanan mempunyai pengaruh signifikan terhadap kepuasan nasabah.

Hasil pengujian uji $t$ menunjukkan bahwa seluruh variabel bebas yaitu variabel responsiveness, Tangibles, Empathy, Assurance, dan Reliability secara parsial mempunyai pengaruh yang signifikan terhadap kepuasan nasabah di PT. Bank Central Asia (BCA) Tbk Cabang Undaan Surabaya, dibuktikan berdasarkan nilai $t_{\text {hitung }}$ lebih besar dari $t_{\text {tabel }}$ dan nilai signifikansinya lebih kecil dari alpha $(\alpha)$ yang bernilai 0,05 . Penelitian ini sesuai dengan penelitian yang dilakukan oleh Hartono (2006) yang menyimpulkan bsik secara simultan maupun secara parsial kualitas pelayanan mempunyai pengaruh signifikan terhadap kepuasan nasabah. 


\section{SIMPULAN DAN SARAN}

\section{Simpulan}

1. Terdapat pengaruh secara serempak responsiveness, tangibles, empathy, assurance, reliability terhadap kepuasan nasabah Bank Central Asia (BCA) Tbk Cabang Undaan Surabaya.

2. Terdapat pengaruh secara parsial responsiveness terhadap kepuasan nasabah Bank Central Asia (BCA) Tbk Cabang Undaan Surabaya.

3. Terdapat pengaruh secara parsial tangibles terhadap kepuasan nasabah Bank Central Asia (BCA) Tbk Cabang Undaan Surabaya.

4. Terdapat pengaruh secara parsial empathy terhadap kepuasan nasabah Bank Central Asia (BCA) Tbk Cabang Undaan Surabaya.

5. Terdapat pengaruh secara parsial assurance terhadap kepuasan nasabah Bank Central Asia (BCA) Tbk Cabang Undaan Surabaya.

6. Terdapat pengaruh secara parsial reliability terhadap kepuasan nasabah Bank Central Asia Cabang Undaan Surabaya.

Saran

Berdasarkan koefisien beta, pengaruh yang paling kecil terhadap kepuasan nasabah adalah responsiveness (daya tanggap) yang menggambarkan keinginan untuk menolong pelanggan dan untuk menyediakan layanan yang cepat dan tepat masih kurang. Berdasarkan hal tersebut diharapkan untuk masa yang akan datang responsiveness dari seluruh karyawan BCA dapat lebih ditingkatkan lagi agar dapat memuaskan para nasabahnya dalam memberikan pelayanan di bidang perbankan. Disamping itu demi meningkatkan kualitas pelayanan di PT. Bank Central Asia (BCA) Tbk Cabang Undaan Surabaya sebaiknya para karyawan selalu diberi pengarahan dan pelatihan - pelatihan bagaimana caranya melayani para nasabah dengan baik,sehingga para nasabah yang datang ke bank tidak hanya sekedar untuk memenuhi kebutuhannya saja, melainkan para nasabah juga akan merasa puas atas pelayanan yang diberikan oleh karyawan-karyawan BCA. 


\section{DAFTAR PUSTAKA}

Bahrul Kirom, 2009. Mengukur Kinerja Pelayanan dan Kepuasan Konsumen, Pustaka Reka Cipta bandung.

Dermawan wibisono, Ph.D, 2006. Manajemen Kinerja, Erlangga Surabaya.

Fandy Tjiptono \& Gregorius Chandra, 2005. Service, Quality, \& Satisfaction, Andi Yogyakarta.

Imam Ghozali, 2005. Aplikasi Analisis Multivariate Dengan Program SPSS, Universitas Diponegoro Semarang.

Jill Griffin, 2003. Customer Loyalty, Erlangga Surabaya.

Kotler, Philip dan Susanto, A.B, 2000. Manajemen Pemasaran di Indonesia. Analisis

Perencanaan, Implementasi dan Pengendalian, edisi pertama. Jakarta: Salemba Empat.

Kasmir, 2001. Bank dan Lembaga Keuangan Lainnya, PT Raja Grafindo Persada Jakarta.

Lupiyoadi, Rambat, 2001. Manajemen Pemasaran Jasa Teori dan Praktik, Salemba Empat Jakarta.

Murti Sumarni \& Salamah Wahyuni, 2005. Metodologi Penelitian Bisnis, Andi.

Nina Rahmayanty, 2010. Manajemen Pelayanan Prima, Graha Ilmu Yogyakarta.

Naresh Malhotra, 1996. Marketing Research, Second Edition, Prentice Hall.

Riduwan, 2009. Metode dan Teknik Menyusun Proposal Penelitian, Alfabeta. Bandung.

Santoso, Singgih, 2003. Statistik Diskriptif, Andi Yogyakarta.

Sugiono, 2007. Metode Penelitian Kuantitatif, Kualitatif dan R\&D, CV. Alfabeta. Bandung.

Saifuddin Azwar, 1997. Metode Penelitian, Pustaka Pelajar Yogyakarta. 